\title{
Assessment of enteric viruses in a sewage treatment plant located in Porto Alegre, southern Brazil
}

\author{
Vecchia, AD. ${ }^{a, b}$, Fleck, JD. ${ }^{a, b}$, Kluge, M. ${ }^{b}$, Comerlato, J. ${ }^{c}$, Bergamaschi, B. ${ }^{c}$, \\ Luz, RB. ${ }^{b}$, Arantes, TS. ${ }^{c}$, Silva, JVS. ${ }^{b}$, Thewes, MR. ${ }^{d}$ and Spilki, FR. ${ }^{a, b *}$ \\ aPrograma de Pós-graduação em Qualidade Ambiental, Universidade Feevale, \\ Rod. RS-239, 2755, CEP 93352-000, Novo Hamburgo, RS, Brazil \\ bLaboratório de Microbiologia Molecular, Instituto de Ciências da Saúde, Universidade Feevale, \\ Rod. RS-239, 2755, CEP 93352-000, Novo Hamburgo, RS, Brazil \\ 'Laboratório de Virologia, Departamento de Microbiologia, Instituto de Ciências Básicas da Saúde, Universidade Federal \\ do Rio Grande do Sul - UFRGS, Av. Sarmento Leite, 500, CEP 90050-170, Porto Alegre, RS, Brazil \\ ${ }^{\mathrm{d}}$ Departamento Municipal de Água e Esgoto, Divisão de Pesquisa, Praça Montevidéo, 10, \\ CEP 90010-170, Porto Alegre, RS, Brazil \\ *e-mail: fernandors@feevale.br \\ Received September 9, 2011 - Accepted November 29, 2011 - Distributed November 30, 2012
}

(With 1 figure)

\begin{abstract}
In order to verify the microbial quality of the influents and effluents of one STP from southern Brazil, an eight-month survey was conducted to examine the presence of total and fecal coliforms and of adenovirus (HAdV), enterovirus (EV), genogroup A rotaviruses (GARV) and Torque teno virus (TTV), in treated effluent samples from São João/ Navegantes STP, Porto Alegre (Brazil). A total of 16 samples were collected, eight of influent (raw sewage, prior to treatment), and the other eight of the effluent (post-treatment sewage). Total and fecal coliform levels ranging from $3.6 \times 10^{4}$ to $4.4 \times 10^{7} \mathrm{MPN} / 100 \mathrm{~mL}$ and $2.9 \times 10^{3}$ to $1.7 \times 10^{7} \mathrm{MPN} / 100 \mathrm{~mL}$, were detected in all samples. In raw sewage, HAdV (25\%) and GARV (28.6\%) viral genomes were detected. The analysis of effluent samples revealed the presence of HAdV (50\%), EV (37.5\%), and TTV (12.5\%) genomic fragments. All samples, regardless of the month analysed, presented detection of a least one virus genus, except for in April. Higher virus detection rates were observed in treated sewage samples (62.5\%), and in $80 \%$ of them (effluent positive samples) HAdV was detected. Results showed that improvements in sewage monitoring and treatment processes are necessary to reduce the viral and bacterial load on the environment in southern Brazil. To the knowledge of the authors, this is the first study showing the monitoring of viral genomes in influent and effluent samples from a STP located in Porto Alegre (Rio Grande do Sul, Brazil), southern Brazil.
\end{abstract}

Keywords: sewage treatment plant, wastewater, microbial analysis of sewage, enteric viruses, coliforms.

\section{Avaliação de vírus entéricos em uma estação de tratamento de esgoto localizada em Porto Alegre, sul do Brasil}

\section{Resumo}

Com o intuito de verificar a qualidade microbiológica de afluentes e efluentes de uma estação de tratamento de esgoto (ETE), um monitoramento de oito meses foi realizado para examinar a presença de coliformes totais e fecais, e de adenovírus (HAdV), enterovírus (EV), rotavírus do genogrupo A (GARV) e torque teno vírus (TTV), em amostras de esgoto tratado da ETE São João/Navegantes, em Porto Alegre-RS, Brasil. Um total de 16 amostras foi coletado, sendo oito de afluente (esgoto bruto, anterior ao tratamento) e oito de efluente (esgoto tratado). Os níveis de coliformes totais

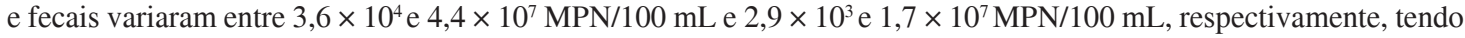
sido estes detectados em todas as amostras. No esgoto bruto, foram detectados os genomas virais de HAdV (25\%) e GARV (28,6\%). A análise das amostras de efluente revelou a presença de fragmentos genômicos de HAdV (50\%), EV (37,5\%) e TTV (12,5\%). Todas as amostras, independentemente do mês analisado, possibilitaram a detecção de pelo menos um gênero viral, exceto no mês de abril. Altas taxas de detecção viral foram observadas em amostras de esgoto tratado (62,5\%), sendo que o HAdV foi detectado em $80 \%$ dessas amostras de efluente positivas. Os resultados mostram que aprimoramentos no processo de tratamento e monitoramento do esgoto são necessários para reduzir a carga viral e bacteriológica no ambiente do Sul do Brasil. Ao conhecimento dos autores, este é o primeiro estudo de monitoramento de genomas virais em amostras de afluente e efluente de uma ETE localizada em Porto Alegre-Rio Grande do Sul, Brasil.

Palavras-chave: estação de tratamento de esgoto, efluente, análise microbiológica do esgoto, vírus entéricos, coliformes. 


\section{Introduction}

Most treated wastewater, as well as untreated sewage, flow into the environmental water bodies and harbors the potential to impact agricultural, recreational and drinking related water uses. Currently, bacterial indicators, such as total and fecal coliforms (Escherichia coli), are still commonly employed as the only bioindicator to verify the microbial quality of water (WHO, 2008), specially in South America. These pathogens are relatively easy and inexpensive to monitor; however, their absence does not exclude putative fecal contamination with different viruses excreted in feces from both ill and healthy individuals (Goyal et al., 1984; Jiang and Chu, 2004; Fong et al., 2005).

Human enteric viruses are causative agents of many non-bacterial gastrointestinal and respiratory tract infections, as well as other clinical syndromes, including conjunctivitis, hepatitis and other diseases with high morbidity and mortality in immunocompromised individuals such as aseptic meningitis, encephalitis, myocardits and acute flaccid paralysis (Kapikian et al., 2001; Pallansch and Roos, 2001; Carter, 2005; Lenaerts et al., 2008; Okoh et al., 2010). These agents infect and replicate in the gastrointestinal tract of their hosts and are released in large quantities in the stools of infected individuals, about $10^{5}$ to $10^{11}$ virus particles per gramme of stool (Bosch, 1998).

The majority of these viruses are non-enveloped, which makes them highly resistant in the water environment, as well as more resistant to decontamination processes used in both drinking and wastewater treatment (Rose et al., 1991; Gerba et al., 2002; Sobsey and Meschke, 2003; Bosh et al., 2006; Bofill-Mas et al., 2006). Many studies have found that, despite the treatment applied, enteric viruses may persist in high levels in wastewaters (He and Jiang, 2005; Villar et al., 2007; Carducci et al., 2008; Fong et al., 2010; Kokkinos et al., 2010; La Rosa et al., 2010a, b; Prado et al., 2011), proposing the use of a viral indicator of treated sewage contamination.

The most commonly studied species of enteric viruses are adenovirus (HAdV), enterovirus (EV), genogroup A rotaviruses (GARV), hepatitis $\mathrm{A}$ and $\mathrm{E}$ viruses and more recently, norovirus (Leclerc et al., 2002; Fong and Lipp, 2005; Abdel-Moety et al., 2008; Gibson et al., 2011). Similarly to the enteric viruses, Torque teno virus (TTV), an emerging virus discovered from hepatitis patients and healthy persons as well, exhibits similar behaviour: it is relatively resistant to heat inactivation and also excreted by the fecal route. However, its role as a pathogenic agent remains unclear (Wilhelmi et al., 2003).

$\mathrm{AdV}$ are members of Adenoviridae family, which comprises non-enveloped viruses with linear doublestranded DNA, with a diameter of 80-110 nm (ICTV, 2006). Enteroviruses are positive-sense RNA viruses, 22-30 $\mathrm{nm}$ in diameter (Rajtar et al., 2008), belonging to the Enterovirus genus of the Picornaviridae family, order Picornavirales (ICTV, 2009). Rotaviruses are members of the Reoviridae family, genus Rotavirus (ICTV, 2009), possessing a non-enveloped particle measuring $80 \mathrm{~nm}$ of diameter which contain a genome consisting of 11 segments of double-stranded RNA (ICTV, 2006). TTV are non-enveloped viruses with a single-stranded circular (negative-sense) DNA genome, measuring 30-32 nm (ICTV, 2006; Biagini, 2009). Currently, TTV is classified within the Anelloviridae family (ICTV, 2009).

The monitoring of sewage treatment plants (STPs) may prove a suitable approach for the study of circulating viruses and the persistence of such viruses in treated effluent. In Brazil, some studies have been carried out for this purpose (Villar et al., 2007; Barrella et al., 2009; Victoria et al., 2010; Prado et al., 2011), nevertheless, to the knowledge of the authors, none of them was performed in the state of Rio Grande do Sul. Porto Alegre, the capital of the state (Figure 1), is covered by twelve STPs (Porto Alegre, 2011). STP called São João/Navegantes receives urban sewage from eleven neighbourhoods of the north region of the city and assists approximately 150,000 inhabitants (Porto Alegre, 2011). This STP was installed by DMAE (Municipal Department of Water and Sewage) at the end of 2000 and has a nominal capacity of 444 litres per second (Porto Alegre, 2011). The sewage treatment is performed by a conventional activated sludge treatment process, and the treated effluents are discharged near the Gravataí river mouth. Thus, to enrich the existing data on the virological quality of the influents and effluents of STP in southern Brazil, and specially in the larger city of Rio Grande do Sul, an eight-month survey was conducted to examine the presence of HAdV, EV, GARV and TTV in treated effluent samples from São João/Navegantes STP.

\section{Material and Methods}

\subsection{Water samples}

Water samples (500 mL each) were collected aseptically in the sewage treatment plant (STP) called São João/ Navegantes, DMAE, Porto Alegre, Brazil. Influent and

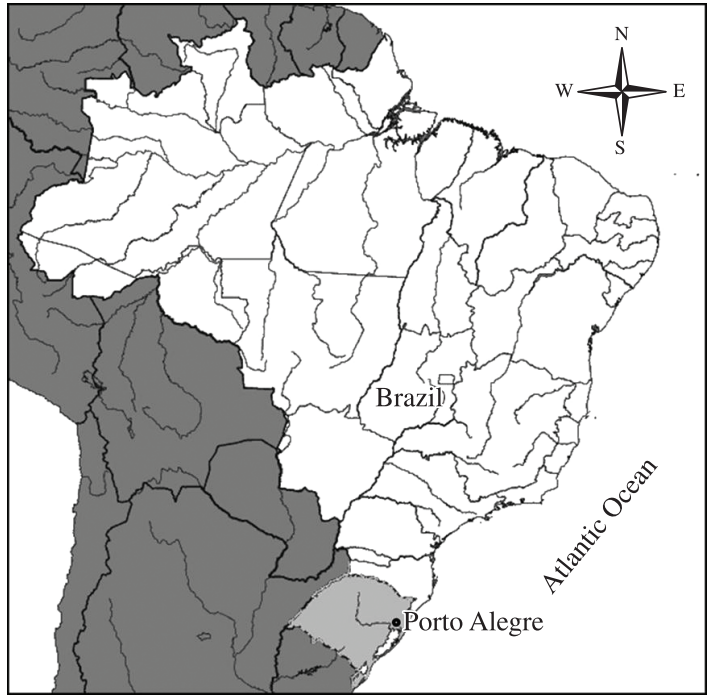

Figure 1. Location of the city of Porto Alegre. 
effluent sampling were carried out monthly from March to October, 2009. A total of 16 samples were collected, eight of influent (raw sewage, prior to treatment), and the other eight of the effluent (post-treatment sewage) taken directly from São João/Navegantes STP, in sterilised glass bottles previously acclimatised with the water system. The samples were transported to the laboratory under refrigeration $\left(4^{\circ} \mathrm{C}\right)$, and were kept under these conditions until sample concentration.

\subsection{Sample concentration}

Putative viruses present in the samples were concentrated using an adsorption-elution method with negatively charged membranes (HA, Millipore, USA), as previously described by Katayama et al. (2002), with minor modifications. Briefly, $0.6 \mathrm{~g}$ of $\mathrm{MgCl}_{2} \cdot 6 \mathrm{H}_{2} \mathrm{O}$ was mixed with $500 \mathrm{~mL}$ of each water sample and $\mathrm{pH}$ was adjusted to 5.0 using a solution of $10 \% \mathrm{HCl}$. Subsequently, the resulting mixture was vacuum filtered through a negatively sterile membrane (type HA, $0.45 \mu \mathrm{m}$ pore size; $47 \mathrm{~mm}$ diameter). The membrane was rinsed with $87.5 \mathrm{~mL}$ of a $0.5 \mathrm{mM} \mathrm{H}_{2} \mathrm{SO}_{4}$ ( $\mathrm{pH}$ 3.0) followed by elution of viral particles adsorbed to the membrane with $2.5 \mathrm{~mL}$ of $1 \mathrm{mM} \mathrm{NaOH}$ (pH 10.5). The filtrate was then neutralised with $12.5 \mu \mathrm{L}$ of $50 \mathrm{mM}$ $\mathrm{H}_{2} \mathrm{SO}_{4}$ and $12.5 \mu \mathrm{L}$ in $100 \mathrm{X}$ Tris-EDTA (TE) buffer. The resulting mixture was aliquoted and stored at $-80{ }^{\circ} \mathrm{C}$ until further processing.

\subsection{Viral nucleic acid extraction}

The commercial kit RTP DNA/RNA Virus Mini Kit (Invitek, Berlin, Germany) was employed for extraction of viral nucleic acids (DNA, HAdV and TTV; RNA, EV and GARV), according to the manufacturer's instructions. The viral DNA or RNA obtained was stored in a freezer at $-80{ }^{\circ} \mathrm{C}$ for later processing.

\subsection{Polymerase chain reaction}

In order to achieve amplification of EV and GARV genomes, an additional step was carried out before amplification, i.e. cDNA synthesis, which was obtained with High Capacity cDNA Reverse Transcription commercial kit (Applied Biosciences, USA), with the aid of random primers, following the manufacturer's instructions.

PCR conditions were optimised and reactions were standardised as follows: (a) HAdV and GARV: $50 \mu \mathrm{L}$ reaction mixtures consisting $25 \mu \mathrm{L}$ of GoTaq ${ }^{\circledR}$ Green Master Mix (Promega, USA), $18 \mu \mathrm{L}$ of nuclease-free water, $1 \mu \mathrm{L}$ of each primer $(20 \mathrm{pM})$ and $5 \mu \mathrm{L}$ of nucleic acid; (b) EV: $25 \mu \mathrm{L}$ final volume containing $12,5 \mu \mathrm{L}$ of $2 \mathrm{x}$ PCR Master Mix $^{\text {tm }}$ (LGCbio, Brazil), 7.5 $\mu \mathrm{L}$ of nuclease-free water, 1 $\mu \mathrm{L}$ of each primer (20 pM) and $3 \mu \mathrm{L}$ of cDNA product; (c) TTV: final volume of $50 \mu \mathrm{L}$ containing $25 \mu \mathrm{L}$ of $2 \times$ PCR Master Mix $^{\text {tm }}$ (LGCbio, Brazil), $22.5 \mu \mathrm{L}$ of nuclease-free water, $0.5 \mu \mathrm{L}$ of each primer $(20 \mathrm{pM})$ and $1.0 \mu \mathrm{L}$ of extracted DNA. DNase/RNase free water was used as a negative control during all PCR assays. The positive controls used in amplifications were Poliovirus-1 (Sabin strain), kindly provided by Dr. Carlos Nozawa; HAdV types 2 and 5, kindly provided by Dr. Célia Barardi; Human-GARV (VP6 I-2 Genotype), isolated from a clinical sample collected in the municipality of Porto Alegre, and a 100-fold diluted solution containing a TTSV (Torque Teno Sus Virus) cloned genome, provided by Dr. Paulo Michel Roehe. The sequences of the primers and their location in the virus genomes are given in Table 1 (Vecchia et al., 2012).

Amplification of the target genomic fragments was performed using a thermal cycler (MultiGene, Labnet International, USA). The PCR conditions were optimised for each virus group and were as follows: (a) HAdV: $98^{\circ} \mathrm{C}$ for 7 minutes, 40 cycles of $94^{\circ} \mathrm{C}$ for 1 minute, $55^{\circ} \mathrm{C}$ for 1 minute, $72{ }^{\circ} \mathrm{C}$ for 1 minute; (b) $\mathrm{EV}: 98{ }^{\circ} \mathrm{C}$ for 5 minutes, 35 cycles of $94{ }^{\circ} \mathrm{C}$ for 1 minute, $56{ }^{\circ} \mathrm{C}$ for 1 minute, $72{ }^{\circ} \mathrm{C}$ for 1 minute; (c) GARV: $94{ }^{\circ} \mathrm{C}$ for 5 minutes, 40 cycles of $94{ }^{\circ} \mathrm{C}$ for 1 minute, $54{ }^{\circ} \mathrm{C}$ for 1 minute (which was decreased by $0.5^{\circ} \mathrm{C}$ at each of the 39 subsequent cycles), $72{ }^{\circ} \mathrm{C}$ for 1 minute; (d) TTV: $94{ }^{\circ} \mathrm{C}$ for 2 minutes, 40 cycles of $94{ }^{\circ} \mathrm{C}$ for 1 minute, $59{ }^{\circ} \mathrm{C}$ for 30 seconds, $72{ }^{\circ} \mathrm{C}$ for 30 seconds. After cycles all reactions were left at $72{ }^{\circ} \mathrm{C}$ for 7 minutes for final elongation.

Table 1. Primers and conditions used for amplification of HAdV, EV, GARV and TTV in PCR (according to Vecchia et al., 2012).

\begin{tabular}{|c|c|c|c|c|c|c|c|}
\hline \multirow{2}{*}{ Viruses } & \multirow{2}{*}{$\begin{array}{l}\text { Target } \\
\text { Gene }\end{array}$} & \multicolumn{3}{|c|}{ Primer } & \multirow{2}{*}{ Position } & \multirow{2}{*}{$\begin{array}{c}\text { Annealing } \\
\text { temperature }\end{array}$} & \multirow{2}{*}{$\begin{array}{c}\text { Amplicon } \\
\text { length }\end{array}$} \\
\hline & & Name & Sequence & Polarity & & & \\
\hline \multirow[t]{2}{*}{$\mathrm{AdV}$} & Hexon & VTB2-HAdVCf & 5'-GAGACGTACTTCAGCCTGAAT-3' & Sense & $106-126^{A}$ & $55^{\circ} \mathrm{C}$ & $101 \mathrm{bp}$ \\
\hline & & VTB2-HAdVCr & 5'-GATGAACCGCAGCGTCAA-3' & Reverse & $190-207^{A}$ & & \\
\hline \multirow[t]{2}{*}{ EV } & 5'UTR & ENT-F1 & 5'-CCTCCGGCCCCTGAATG-3' & Sense & $443-459^{B}$ & $56^{\circ} \mathrm{C}$ & $116 \mathrm{bp}$ \\
\hline & & ENT-R2 & 5'-ACACGGACACCCAAAGTAG-3' & Reverse & $541-559^{C}$ & & \\
\hline \multirow[t]{2}{*}{ GARV } & VP6 & ROTAFEEVALE-FW & 5'-GATGTCCTGTACTCCTTGT-3' & Sense & $7-25^{D}$ & $54{ }^{\circ} \mathrm{C}^{F}$ & $160 \mathrm{bp}$ \\
\hline & & ROTAFEEVALE-REV & 5'-GGTAGATTACCAATTCCTCC-3' & Reverse & $148-167^{D}$ & & \\
\hline \multirow[t]{3}{*}{ TTV } & ORF2 & $\mathrm{F} 1$ & 5'-GGGAGCTCAAGTCCTCATTTG-3' & Sense & $221-241^{E}$ & $59{ }^{\circ} \mathrm{C}$ & $102 \mathrm{bp}$ \\
\hline & & $\mathrm{F} 2$ & 5'-GGGCCWGAAGTCCTCATTAG-3' & Sense & $170-189^{E}$ & & \\
\hline & & Rev & 5'-GCGGCATAAACTCAGCCATTC-3' & Reverse & $252-272^{E}$ & & \\
\hline
\end{tabular}

${ }^{A}$ Primers sequences reported by Wolf et al. (2010); ${ }^{B}$ Primers sequences reported by Tsai et al. (1993); ${ }^{C}$ This work, Genome position of primers based on GenBank accession number FJ859064; ${ }^{D}$ This work, Genome position of primers based on GenBank accession number HM348746; ${ }^{E}$ This work, Genome position of primers based on GenBank accession number FN687866; ${ }^{F}$ Initial annealing temperature, which was decreased by $0.5^{\circ} \mathrm{C}$ at each of the 39 subsequent cycles (Touchdown-PCR). 
To determine the analytical sensitivity of the assays, 10-fold serial dilutions of each DNA/RNA standard were employed. EV-PCR has shown to detect a minimum of 0.316 tissue culture infective doses $\left(\mathrm{TCID}_{50}\right.$ ) of experimentally contaminated water, to HAdV-PCR the value was 0.562 $\mathrm{TCID}_{50}$. On the specific case of GARV, the amount of DNA used for amplification was measured by comparison with Low Mass DNA ladder (Invitrogen, USA) and the detection limit determined as $200 \mathrm{ng}$ per sample. To determine the TTV-PCR sensibility an additional step was required before serial dilution, i. e. plasmid cloning. The assay was able to detect a minimal 10 DNA plasmid copies diluted in $500 \mathrm{~mL}$ water samples.

After the reactions, $\mathrm{PCR}$ products were stained with nontoxic fluorescent dye Blue Green (LGCBio, Brazil), analysed by electrophoresis on $2 \%$ (w/v) agarose gel and visualised under ultraviolet (UV) light.

\subsection{Coliform detection}

Coliform detection and counting was performed through Colilert ${ }^{\circledR}$ commercial kit (Idexx Laboratories Inc., USA), according to the manufacturer's instructions.

\section{Results}

Water samples were taken monthly from March to October 2009, in the STP São João/Navegantes. Eight samples of influent (raw sewage, prior to treatment) and eight samples of effluent (post-treatment sewage) were analysed by conventional PCR for the presence of HAdV, EV, GARV and TTV, and by Colilert ${ }^{\circledR}$ commercial kit (Idexx Laboratories Inc., USA) for coliform presence.

$\mathrm{AdV}$ was detected in two out of eight (25\%) influent samples and four out of eight (50\%) effluent samples. EV was not detected in influent samples and it was detected in three out of eight $(37.5 \%)$ effluent samples. GARV was detected in two out of seven (28.6\%) influent samples analysed and it was not detected in effluent samples. TTV was not detected in influent samples and it was detected in one out of eight $(12.5 \%)$ effluent samples analysed. Results are summarised in Table 2. All sampling months presented detection of a least one group of virus, except for
April. Higher virus detection rate was observed in treated sewage samples $(62.5 \%)$, and in $80 \%$ of them (effluent positive samples) HAdV genomes were found.

All samples presented both total and fecal coliforms. For raw sewage samples, total coliforms yielded a population density from $9.9 \times 10^{6}$ to $4.4 \times 10^{7}$ most probable number $(\mathrm{MPN}) / 100 \mathrm{~mL}$, the density of fecal coliforms ranged from $1.6 \times 10^{6}$ to $1.7 \times 10^{7} \mathrm{MPN} / 100 \mathrm{~mL}$. For effluent samples, total coliform concentration ranged from $3.6 \times 10^{4}$ to $6.1 \times 10^{5} \mathrm{MPN} / 100 \mathrm{~mL}$, and fecal coliform concentration ranged from $2.9 \times 10^{3}$ to $6.1 \times 10^{4} \mathrm{MPN} / 100 \mathrm{~mL}$. Results are summarised in Table 2.

\section{Discussion}

Microbial monitoring was performed monthly during eight months in a STP in Porto Alegre city, Brazil. The presence of total and fecal coliforms, as well as HAdV, EV, GARV and TTV was evaluated. A total of 16 samples were collected: eight of influent (raw sewage) and eight of effluent (treated sewage). In this study, the highest viral detection rate was observed in effluent samples (62.5\%), different of Victoria et al. (2010), who found the highest viral detection rate (norovirus, not assayed in the present study) in influent samples of a STP in Rio de Janeiro (Brazil). The detection of highest rates for viral detection in treated sewage samples has been previously reported by other authors, such as Fong et al. (2010), He and Jiang (2005), which could be caused by the presence of a higher level of PCR inhibitory substances in raw sewage. However, the PCR inhibitor assays applied to all samples (including negative and positive samples) showed only one influent sample, in which the presence of PCR inhibitors could affect the result (data not shown).

The presence of at least one group of virus was detected in all sampling occasions, except for April, being HAdV the main virus group detected. The highest HAdV prevalence agrees with the findings of Myrmel et al. (2006), Carducci et al. (2008, 2009), Symonds et al. (2009) and La Rosa et al. (2010a), which suggest that HAdV could be a useful indicator of fecal contamination. According

Table 2. Detection of HAdV, EV, GARV and TTV genomes, and coliform quantification, in influent and effluent samples collected from São João/Navegantes STP, Porto Alegre, Brazil.

\begin{tabular}{|c|c|c|c|c|c|c|c|}
\hline & & \multicolumn{6}{|c|}{ Microbiological parameters } \\
\hline & & AdV & $\mathbf{E V}$ & GARV & TTV & $\begin{array}{l}\text { Total coliform counting } \\
(\text { MPN/100 mL) }\end{array}$ & $\begin{array}{l}\text { Fecal coliform counting } \\
(\mathrm{MPN} / 100 \mathrm{~mL})\end{array}$ \\
\hline Collection & Mar./09 & $-1-$ & $-1+$ & NT/- & $-1-$ & $4.2 \times 10^{7} / 6.1 \times 10^{5}$ & $1.7 \times 10^{7} / 1.2 \times 10^{5}$ \\
\hline Date & Apr./09 & $-1-$ & $-1-$ & $-1-$ & $-1-$ & $4.4 \times 10^{7} / 4.4 \times 10^{4}$ & $8.7 \times 10^{6} / 1.1 \times 10^{4}$ \\
\hline & May/09 & $-/+$ & $-1+$ & $-1-$ & $-1-$ & $1.3 \times 10^{7} / 1.1 \times 10^{5}$ & $3.1 \times 10^{6} / 1.8 \times 10^{4}$ \\
\hline & June/09 & $-1+$ & $-1+$ & $-/ \mathrm{NT}$ & $-1-$ & $2.0 \times 10^{7} / 5.2 \times 10^{5}$ & $6.5 \times 10^{6} / 5.8 \times 10^{4}$ \\
\hline & July/09 & $+/-$ & $-1-$ & $-1-$ & $-1-$ & $1.6 \times 10^{7} / 1.2 \times 10^{5}$ & $1.6 \times 10^{7} / 6.1 \times 10^{4}$ \\
\hline & Aug./09 & $-/+$ & $-1-$ & $+1-$ & $-1-$ & $1.7 \times 10^{7} / 1.2 \times 10^{5}$ & $3.1 \times 10^{6} / 2.5 \times 10^{4}$ \\
\hline & Sept./09 & $-1+$ & $-1-$ & $-1-$ & $-1+$ & $9.9 \times 10^{6} / 3.6 \times 10^{4}$ & $1.6 \times 10^{6} / 2.5 \times 10^{4}$ \\
\hline & Oct./09 & $+1-$ & $-1-$ & $+1-$ & $-1-$ & $1.4 \times 10^{7} / 5.1 \times 10^{4}$ & $2.4 \times 10^{6} / 2.9 \times 10^{3}$ \\
\hline
\end{tabular}

Results are showed as influent/effluent; + and -, detected and not detected, respectively; N/T, not tested. 
to these authors, the highest HAdV detection rate may be related to its high stability in the environment. Besides, adenoviruses are known for their high resistance to UV light when compared to other enteric viruses (Gerba et al., 2002), a fact that must be considered for the application of UV disinfection technologies used in wastewater treatments.

Bofill-Mas et al. (2006) quantified and evaluated the stability of adenovirus and polyomavirus JCPyV in a wastewater treatment plant in Barcelona (Spain). Results showed high stability for both viruses in urban sewage, which were found in high quantities in sewage and effluent, as well as sludge and biosolid samples.

A similar study conducted by Kokkinos et al. (2010) evaluated the presence of EV, HAdV and hepatitis A virus (HAV) in influent and effluents samples from a primary treatment wastewater plant in Greece, in a period of 8 months. Both EV and HAdV were detected in 40\% (10/25) of raw sewage, which were simultaneously present in $15 \%$ of the samples. HAdV was more prevalent, as observed for treated sewage, being present on $44 \%$ (11/25) of effluent samples, while EV reached $12 \%$ (3/25). The prevalence of HAV was low, with no positive results for treated sewage/ effluent samples.

Dubois et al. (1997) has monitored influent and effluent samples in western France during one year for the presence of rotaviruses. The results showed $42 \%$ of positivity in raw sewage and $67 \%$ in treated effluent samples. In this study, HAdV (25\%) and GARV (28.6\%) were detected in influent, which were simultaneously present in $12.5 \%$ of the samples. In the present study, GARV was not detected in treated sewage.

The analysis of effluent samples revealed the presence of HAdV (50\%), EV (37.5\%), and TTV (12.5\%), being detected simultaneously HAdV and EV in $25 \%$ of the assayed samples and HAdV and TTV, in $12.5 \%$. The HAdV and $\mathrm{EV}$ rates in treated sewage samples were higher than those found by Kokkinos et al. (2010) in Greece, but lower than those found by La Rosa et al. (2010a) in Italy, who detected HAdV in $96 \%$ of influent samples and in $76 \%$ of effluent samples, and EV in $96 \%$ and $84 \%$ in influents and effluents, respectively.

The evaluation of TTV presence on STP influents and effluents was performed by Vaidya et al. (2002) in India, and Haramoto et al. (2005) in Japan. The first study detected TTV in $14.5 \%$ of raw sewage samples and $2 \%$ of these remained positive after treatment. In Japan, however, TTV detection rates were higher (Haramoto et al., 2005). The authors found TTV in $97 \%, 18 \%$ and $24 \%$ of influent, secondary effluent samples (before chlorination) and final effluent samples (after chlorination), respectively.

The evaluation of HAdV, EV, GARV, TTV and HAV presence was also performed by Carducci et al. (2009) in Italy. The authors detected HAdV in $100 \%$ of the samples collected at both raw and treated sewage, TTV in $72 \%$ and $62 \%$ of raw and treated sewage samples and GARV in $100 \%$ and $33 \%$ of tested influent and effluent samples, respectively. These viral detection rates were higher than those observed in the present study. EV and HAV were not found in assayed samples by Carducci et al. (2009).

The low rates for detection of GARV genomes may be associated to the methodology used for concentration of the samples, since other methods were used in the past for this purpose (Berthiaume et al., 1981; Smith and Gerba, 1982). Nevertheless, a number of recent reports described the use of adsorption-elution protocol for the detection of GARV in water and sewage samples (Li et al., 2011; Rigotto et al., 2010), although low percentages of rotavirus genomes were reported.

Another possible pitfall of the present analysis may be associated to the volume of the samples collected, since many studies used more than $500 \mathrm{~mL}$; other studies reported the detection of viral genomes on samples with smaller volumes of crude water or sludge (Symonds et al., 2009; Schvoerer et al., 2001); however, this might be a limitation for some types of water samples.

To the knowledge of the authors, this is the first study showing the monitoring of viral genomes in influent and effluent samples from a STP in Porto Alegre, which is by far the largest city in the southernmost state of Brazil (Rio Grande do Sul). These results confirm the frequent occurrence of enteric viral genomes in sewage effluents, suggesting that treated sewage may represent a source of environmental contamination which may potentially harbor enteric viruses. Despite of the lack of information on virus infectivity necessary for the evaluation of an effective viral deterioration of the process, the levels of viral contamination observed in the effluent should induce precautions for its discharge. The high prevalence of adenoviruses found in effluent samples in the present study and also reported by other authors suggests that HAdV could be a useful indicator of fecal contamination in sewage treatment plants.

As mentioned before, the results of the present study should be viewed with caution specially for the presence of GARV and TTV, with respect to: i) the initial volume used for the viral concentration, since there are studies that use more than $500 \mathrm{~mL}$ and viruses may have been diluted when discharged into water bodies; ii) the methodology used for the concentration of GARV, as there are studies (Berthiaume et al., 1981; Smith and Gerba, 1982) which show that the use of positively charged membranes are more efficient for GARV recovery from water samples and iii) the limited analytical sensibility of conventional PCR when compared to Real-Time PCR. Taking this into consideration, the low number of samples positive for GARV may have due to the adsorption-elution protocol used for viral concentration, as well as the volume used in this process. For further studies, testing other concentration protocols should be required in order to evaluate the methodology that better fits this type of analysis. Another goal for further studies is the quantification of viral genomes using quantitative real-time PCRs, aiming to evaluate the efficiency of virus removal obtained during the treatment using activated sludge and other systems commonly used in Brazil. 
Acknowledgements - Financial support for this work was from the Universidade Feevale and the Brazilian Research Agencies: Conselho Nacional de Desenvolvimento Científico e Tecnológico (CNPq), Coordenação de Aperfeiçoamento de Pessoal de Nível Superior (CAPES) and Fundação de Amparo à Pesquisa do Estado do Rio Grande do Sul (FAPERGS). We would like to thank Dr. Carlos Nozawa (Departamento de Microbiologia, UEL, Brazil) who kindly supplied us Poliovirus-1 (Sabin strain) and Dr. Célia Barardi (Departamento de Microbiologia, Imunologia e Parasitologia, UFSC, Brazil) for kindly providing HAdV-2 and -5 prototype strains. F.R.S. is a CNPq research fellow.

\section{References}

ABDEL-MOETY, NM., AL-FASSI, FA. and ALI, MA., 2008. Health aspects of virological water quality: an overview review. Journal of Applied Sciences Research, vol. 4, no. 10, p. 1205-1215.

BARRELLA, KM., GARRAFA, P., MONEZI, TM., HÁRSI, CM., SALVI, C., VIOLANTE, PABC. and MEHNERT, DU., 2009. Longitudinal study on occurrence of adenoviruses and hepatitis A virus in raw domestic sewage in the city of Limeira, São Paulo. Brazilian Journal of Microbiology, vol. 40, p. 102-107.

BERTHIAUME, L., ALAIN, R., MCLAUGHLIN, B., PAYMENT, P. and TRÉPANIER, P., 1981. Rapid detection of human viruses in faeces by a simple and routine immune electron microscopy technique. Journal of General Virology, vol. 55, p. 223-227. PMid:6170725. http://dx.doi.org/10.1099/0022-1317-55-1-223

BIAGINI, P., 2009. Classification of TTV and related viruses (Anelloviruses). Current Topics in Microbiology and Immunology, vol. 331, p. 21-33. http://dx.doi.org/10.1007/978-3-540-70972-5_2

BOFILL-MAS, S., ALBINANA-GIMENEZ, N., CLEMENTECASARES, P., HUNDESA, A., RODRIGUEZ-MANZANO, J., ALLARD, A., CALVO, M. and GIRONES, R., 2006. Quantification and stability of human adenoviruses and polyomavirus JCPyV in wastewater matrices. Applied and Environmental Microbiology, vol. 72, p. 7894-7896. PMid:17028225 PMCid:1694247. http:// dx.doi.org/10.1128/AEM.00965-06

BOSCH, A., 1998. Human enteric viruses in the water environment: a minireview. International microbiology, vol. 1, p. 191-196. Pmid:10943359.

BOSH, A., PINTÓ, RM., ABAD, FX., 2006. Survival and transport fenteric viroses in the environmental. p. 151-188. Available from: <http://www.ub.edu/microbiologia/viruse/papers/GOY6.pdf>. Access in: 12 jul. 2011

CARDUCCI, A., BATTISTINI, R., ROVINI, E. and VERANI, M., 2009. Viral removal by wastewater treatment: monitoring of indicators and pathogens. Food and Environmental Virology, vol. 1, p. 85-91. http://dx.doi.org/10.1007/s12560-009-9013-x

CARDUCCI, A., MORICI, P., PIZZI, F., BATTISTINI, R., ROVINI, E. and VERANI, M., 2008. Study of the viral removal efficiency in a urban wastewater treatment plant. Water Science and Technology, vol. 58, p. 893-897. http://dx.doi.org/10.2166/ wst. 2008.437

CARTER, M. J., 2005. Enterically infecting viruses: pathogenicity, transmission and significance for food and waterborne infection. Journal of Applied Microbiology, vol. 98, p. 1354-1380. PMid:15916649. http://dx.doi.org/10.1111/j.1365-2672.2005.02635.x

DUBOIS, E., LE GUYADER, F., HAUGARREAU, L., KOPECKA, H., CORMIER, M. and POMMEPUY, M., 1997. Molecular epidemiological survey of rotaviruses in sewage by reverse transcriptase seminested PCR and restriction fragment length polymorphism assay. Applied and Environmental Microbiology, vol. 63, p. 1794-1800. PMid:9143113 PMCid:168473.

FONG, TT. and LIPP, EK., 2005. Enteric viruses of humans and animals in aquatic environments: health risks, detection, and potential water quality assessment tools. Microbiology and Molecular Biology Reviews, vol. 69, no. 2, p. 357-371. PMid:15944460 PMCid:1197419. http://dx.doi.org/10.1128/ MMBR.69.2.357-371.2005

FONG, TT., GRIFFIN, DW. and LIPP, EK., 2005. Molecular assays for targeting human and bovine enteric viruses in coastal waters and their application for library-independent source tracking. Applied and Environmental Microbiology, vol. 71, no. 4, p. 2070-2078. PMid:15812040 PMCid:1082535. http:// dx.doi.org/10.1128/AEM.71.4.2070-2078.2005

FONG, TT., PHANIKUMAR, MS., XAGORARAKI, I. and ROSE, JB., 2010. Quantitative detection of human adenoviruses in wastewater and combined sewer overflows influencing a Michigan River. Applied and Environmental Microbiology, vol. 76, p. 715-723. PMid:19948848 PMCid:2813034. http:// dx.doi.org/10.1128/AEM.01316-09

GERBA, CP., GRAMOS, DM. and NWACHUKU, N., 2002. Comparative inactivation of enteroviruses and adenovirus 2 by UV light. Applied and Environmental Microbiology, vol. 68, no. 10, p. 5167-5169. PMid:12324370 PMCid:126408. http:// dx.doi.org/10.1128/AEM.68.10.5167-5169.2002

GIBSON, KE., OPRYSZKO, MC., SCHISSLER, JT., GUO, Y. and SCHWAB, KJ., 2011. Evaluation of human enteric viruses in surface water and drinking water resources in Southern Ghana. The American Journal of Tropical Medicine and Hygiene, vol. 84, p. 20-29. PMid:21212196 PMCid:3005515. http://dx.doi. org/10.4269/ajtmh.2011.10-0389

GOYAL, SM., ADAMS, WN., O'MALLEY, ML. and LEAR, DW., 1984. Human Pathogenic Viruses at Sewage Sludge Disposal Sites in the Middle Atlantic Region. Applied and Environmental Microbiology, vol. 48, no. 4, p. 758-763. PMid:6334495 PMCid:241609.

HARAMOTO, E., KATAYAMA, H., OGUMA, K., YAMASHITA, H., NAKAJIMA, E. and OHGAKI, S., 2005. One-year monthly monitoring of Torque teno virus (TTV) in wastewater treatment plants in Japan. Water Research, vol. 39, p. 2008-2013. PMid:15925397. http://dx.doi.org/10.1016/j.watres.2005.03.034

HE, J. W. and JIANG, S., 2005. Quantification of enterococci and human adenoviruses in environmental samples by real-time PCR. Applied and Environmental Microbiology, vol. 71, p. 2250-2255. PMid:15870308 PMCid:1087545. http://dx.doi.org/10.1128/ AEM.71.5.2250-2255.2005

Internacional Comittee on Taxonomy of Viruses - ICTV, 2006. Available from: <http://www.ncbi.nlm.nih.gov/ICTVdb/ICTVdB/> Access in: 12 jul. 2011.

Internacional Comittee on Taxonomy of Viruses - ICTV, 2009. Available from: <http://www.ictvonline.org/virusTaxonomy. asp?version=2009>. Access in: 12 jul. 2011

JIANG, SC. and CHU, W., 2004. PCR detection of pathogenic viruses in southern California urban rivers. Journal of Applied Microbiology, vol. 97, p. 17-28. PMid:15186438. http://dx.doi. org/10.1111/j.1365-2672.2004.02269.x 
KAPIKIAN, AZ., HOSHINO, Y. and CHANOCK, RM., 2001. Rotaviruses. In KNIPPE, DM., HOWLEY, PM., GRIFFIN, DE. (Eds.). Fields virology. 4th ed. Philadelphia: Lippincott Williams \& Wilkins. p. 1787-1833.

KATAYAMA, H., SHIMASAKI, A. and OHGAKI, S., 2002. Development of a virus concentration method and its application to detection of enterovirus and Norwalk virus from coastal seawater. Applied and Environmental Microbiology, vol. 68, no. 3, p. 10331039. PMid:11872447 PMCid:123733. http://dx.doi.org/10.1128/ AEM.68.3.1033-1039.2002

KOKKINOS, P., FILIPPIDOU, S., KARLOU, K. and VANTARAKIS, A., 2010. Molecular typing of enteroviruses, adenoviruses, and hepatites A viruses in untreated and treated sewage of a biological treatment plant in Greece. Food and Environmental Virology, vol. 2, p. 89-96. http://dx.doi.org/10.1007/ s12560-010-9036-3

LA ROSA, G., POURSHABAN, M., IACONELLI, M. and MUSCILLO, M., 2010a. Quantitative real-time PCR of enteric viruses in influent and effluent samples from wastewater treatment plants in Italy. Annali dell'Istituto Superiore di Sanità - Environmental Issues of Health Concern, vol. 46, p. 266-273.

-, 2010b. Detection and molecular characterization of noroviruses from five sewage treatment plants in central Italy. Water Research, vol. 44, p. 1777-1784. PMid:20022621. http://dx.doi.org/10.1016/j. watres.2009.11.055

LECLERC, H., SCHWARTZBROD L, L. and DEI-CAS, E., 2002. Microbial agents associated with waterborne. Critical Reviews in Microbiology, vol. 28, no. 4, p. 371-409. PMid:12546197. http:// dx.doi.org/10.1080/1040-840291046768

LENAERTS, L., DE CLERCQ, E. and NAESENS, L., 2008. Clinical features and treatment of adenovirus infections. Reviews in Medical Virology, vol. 8, no. 6, p. 357-374. PMid:18655013. http://dx.doi.org/10.1002/rmv.589

LI, D, GU., AZ., ZENG, SY., YANG, W., HE, M. and SHI, HC., 2011. Monitoring and evaluation of infectious rotaviruses in various wastewater effluents and receiving waters revealed correlation and seasonal pattern of occurrences. Journal of Applied Microbiology, vol. 110, p. 1129-1137. PMid:21276144. http:// dx.doi.org/10.1111/j.1365-2672.2011.04954.x

MYRMEL, M., BERG, EMM., GRINDE, B. and RIMSTAD, E., 2006. Enteric viruses in inlet and outlet samples from sewage treatment plants. Journal of Water and Health, vol. 4, p. 197-209. PMid:16813012.

OKOH, AI., SIBANDA, T. and GUSHA, SS., 2010. Inadequately treated wastewater as a source of human enteric viruses in the environment. International Journal of Environmental Research and Public Health, vol. 7, p. 2620-2637. PMid:20644692 PMCid:2905569. http://dx.doi.org/10.3390/ijerph7062620

PALLANSCH, MA. and ROOS, RP., 2001. Enteroviruses: polioviruses, coxsackieviruses, echoviruses, and newer enteroviruses. In: KNIPPE, DM. and HOWLEY, PM. (Eds.). Fields Virology. 4th ed. Philadelphia: Lippincott Williams and Wilkins. p. 723-75.

Porto Alegre. Departamento Municipal de Água e Esgotos - DMAE, 2011. Available from: <http://www.portoalegre. rs.gov.br/dmae/>. Access in: 12 jul. 2011.

PRADO, T., SILVA, DM., GUILAYN, WC., ROSE, TL., GASPAR, AMC. and MIAGOSTOVICH, MP., 2011. Quantification and molecular characterization of enteric viruses detected in efluents from two hospital wastewater treatment plants. Water Research, vol. 45, p. 1287-1297. PMid:21040941. http://dx.doi.org/10.1016/j. watres.2010.10.012

RAJTAR, B., MAJEK, M., POLANSKI, L., and POLZ-DACEWICZ, M., 2008. Enteroviruses in water environment - A potential threat to public health. Annals of Agriculture and Environmental Medicine, vol. 15, p. 199-203. PMid:19061255.

ROSE, JB., SUN, GS., GERBA, CP. and SINCLAIR, NA., 1991. Microbial quality and persistence of enteric pathogens in graywater from various household sources. Water Research, vol. 25, no.1, p. 37-42. http://dx.doi.org/10.1016/0043-1354(91)90096-9

SCHVOERER, E., VENTURA, M., DUBOS, O., CAZAUX, G., SERCEAU, R., GOURNIER, N., DUBOIS, V., CAMINADE, P., FLEURY, HJ. and LAFON, ME., 2001. Qualitative and quantitative molecular detection of enteroviruses in water from bathing areas and from a sewage treatment plant. Research in Microbiology, vol. 152, p. 179-186. http://dx.doi.org/10.1016/ S0923-2508(01)01190-1

SOBSEY, MD. and MESCHKE, JS., 2003. Virus survival in the environment with special attention to survival in sewage droplets and other environmental media of fecal or respiratory origin. World Health Organization. Available from: <http:// www.unc.edu/courses/2008spring/envr/421/001/WHO_ VirusSurvivalReport_21Aug2003.pdf $>$. Access in: 12 jul. 2011.

SMITH, EM. and GERBA, CP., 1982. Development of a method for detection of human rotavirus in water and sewage. Applied and Environmental Microbiology, vol. 43, p. 1440-1450. PMid:6285825 PMCid:244252.

SYMONDS, EM., GRIFFIN, DW. and BREITBART, M., 2009. Eukaryotic viruses in wastewater samples from the United States. Applied and Environmental Microbiology, vol. 75, p. 1402-1409. PMid:19124584 PMCid:2648173. http://dx.doi.org/10.1128/ AEM.01899-08

TSAI, Y., SOBSEY, MD., SANGERMANO, LR. and PALMER, CJ. 1993. Simple method of concentrating enteroviruses and hepatitis A virus from sewage and ocean water for rapid detection by reverse transcriptase polymerase chain reaction. Applied and Environmental Microbiology, vol. 59, no. 10, p. 3488-3491. PMid:7504433. PMCid:182480.

VAIDYA, SR., CHITAMBAR, SD. and ARANKALL, VA., 2002. Polymerase chain reaction-based prevalence of hepatitis A, hepatitis $\mathrm{E}$ and TT viruses in sewage from an endemic area. Journal of Hepatology, vol. 37, p. 131-136. http://dx.doi.org/10.1016/ S0168-8278(02)00106-X

VECCHIA, AD., FLECK, JD., COMERLATO, J., KLUGE, M., BERGAMASCHI, B., SILVA, JVS., LUZ, RB., TEIXEIRA, TF., GARBINATTO, GN., OLIVEIRA, DV., ZANIN, JG., VAN DER SAND, S., FRANCO, AC., ROEHE, PM. and SPILKI, FR., 2012. First description of Adenovirus, Enterovirus, Rotavirus and Torque teno virus on surface water samples collected from the Arroio Dilúvio, Porto Alegre, Brazil. Brazilian Journal of Biology, vol. 72, no. 2. PMid:20009258.

VICTORIA, M., GUIMARÃES, FR., FUMIAN, TM., FERREIRA, FFM., VIEIRA, CB., SHUBO, T., LEITE, JPG. and MIAGOSTOVICH, MP., 2010. One year monitoring of norovirus in a sewage treatment plant in Rio de Janeiro, Brazil. Journal of Water and Health, vol. 8, p. 158-165. PMid:20698910. http://dx.doi.org/10.2166/wh.2009.012

RIGOTTO, C., VICTORIA, M., MORESCO, V., KOLESNIKOVAS, CK., CORRÊA, AA., SOUZA, DS., MIAGOSTOVICH, MP., SIMÕES, CM. and BARARDI, CR., 2010. Assessment of 
adenovirus, hepatitis A virus and rotavirus presence in environmental samples in Florianopolis, South Brazil. Journal of Applied Microbiology, vol. 109, p. 1979-1987. PMid:17651213. http:// dx.doi.org/10.1111/j.1365-2672.2010.04827.x

VILLAR, LM., DE PAULA, VS., DINIZ-MENDES, L., GUIMARÃES, FR., FERREIRA, FFM., SHUBO, TC., MIAGOSTOVICH, MP., LAMPE, E. and GASPAR, AMC., 2007. Molecular detection of hepatitis A virus in urban sewage in Rio de Janeiro, Brazil. Letters in Applied Microbiology, vol. 45, p. 168-173. PMid:12667234. http://dx.doi.org/10.1111/j.1472765X.2007.02164.X

WILHELMI, I., ROMAN, E. and SÁNCHEZ-FAUQUIER, A., 2003. Viruses causing gastroenteritis. Clinical Microbiology and Infection, vol. 9, no. 4, p. 247-262. http://dx.doi.org/10.1046/ j.1469-0691.2003.00560.x

WOLF, S., HEWITT, J. and GREENING, GE. 2010. Viral multiplex quantitative PCR assays for tracking sources of fecal contamination. Applied and Environmental Microbiology, vol. 76, no. 5, p. 1388-1394. PMid:20061455. PMCid:2832383. http:// dx.doi.org/10.1128/AEM.02249-09

World Health Organization - WHO, 2008. Guidelines for Drinking-water Quality - Recommendations. 3. ed. Geneva: World Health Organization. vol. 1. Available from: $<$ http://www. who.int/water_sanitation_health/dwq/gdwq3rev/en/> Access in: 12 jul. 2011. 